\title{
Inestabilidad, Conflictividad y Violencia Política en Chile, 1925-1941*
}

IgOR GoICOVIC DoNOso

Profesor titular de la Universidad de Santiago de Chile (Chile). Correo electrónico: igor.goicovic@usach. cl. El autor es doctor en Historia de la Universidad de Murcia (España). Coordinador del seminario Internacional sobre Historia de la Violencia en América Latina. Entre sus publicaciones recientes destacamos: "Compromiso político y debates historiográficos en el Chile actual", en Insistir con la esperanza. El compromiso social y político del intelectual, comps Pablo Pozzi, y Paula Godinho (Buenos Aires: CLACSO, 2019); "Sistema de dominación, conflicto político y organización revolucionaria en Chile", en Marx 200 años. Impactos y vigencias en el siglo XXI comp. José Ponce (Valparaíso: Editorial América en Movimiento, 2019) y Trabajadores al poder. El Movimiento de Izquierda Revolucionaria (MIR) y el proyecto revolucionario en Chile, 1965-1994 (Concepción: Ediciones Escaparate, 2016). Entre sus temas de interés están la historia de la conflictividad y la violencia política y la historia de las organizaciones políticas insurgentes.

Recibido: 17 de enero de 2020

Aprobado: 20 de abril de 2020

Modificado: 20 de abril de 2020

Artículo de investigación científica

DOI: https://doi.org/10.15648/hc.39.2021.2960

* Este artículo forma parte del proyecto "Características y dinámicas históricas del conflicto político en Chile (1912-1952)" financiado por el Fondo Nacional de Desarrollo Científico y Tecnológico-FONDECYT N 1171042 y del proyecto "Dinámicas internacionales de la violencia armada" financiado por DICYT POSTDOC031352GD.

Esta publicación está bajo una licencia Creative Commons Reconocimiento-NoComercial 4.0 (cc) BY-NC 


\section{Inestabilidad, Conflictividad y Violencia Política en Chile, 1925-1941}

\section{Resumen}

Hacia comienzos de la década de 1920 se abrió en Chile un escenario de inestabilidad institucional, derivado de la crisis del régimen oligárquico y de la consolidación política de los movimientos clasistas. Esta crisis, que se extendió hasta la llegada al poder del Frente Popular (1938), escaló hacia crecientes niveles de violencia, la que involucró tanto a grupos antagónicos, como a movimientos ideológicamente afines. En este artículo analizamos los escenarios y los actores que configuraron los escenarios del conflicto político en Chile e identificamos las dinámicas que adquirió la violencia.

Palabras clave: inestabilidad, conflictividad, violencia, movimientos políticos, Chile.

\section{Instability, Conflict and political violence in Chile, 1925-1941}

\section{Abstract}

In the early 1920s, Chile experienced institutional instability due to the oligarchic regime crisis and the political consolidation of class movements. This crisis, which extended right until the arrival to power of the Frente Popular (1938), escalated to increasing levels of violence, involving both antagonist groups and ideologically related movements. This article analyses the circumstances and actors that shaped the scenarios of political conflict in Chile and identifies the dynamics that violence acquired.

Key words: Instability, conflict, violence, political movements, Chile.

\section{Instabilidade, Conflito e Violência Política no Chile, 1925-1941}

\section{Resumo}

No início da década de 1920, um cenário de instabilidade institucional foi aberto no Chile, decorrente da crise do regime oligárquico e da consolidação política dos movimentos de classe. Essa crise, que se estendeu até a Frente Popular chegar ao poder (1938), aumentou para níveis crescentes de violência, envolvendo grupos antagônicos e relacionados ideologicamente. Neste artigo, analisamos os cenários e os atores que configuraram o conflito político no Chile e identificamos as dinâmicas que a violência adquiriu.

Palavras-chave: instabilidade, conflito, violência, movimentos políticos, Chile. 


\section{Instabilité, conflits et violence politique au Chili, 1925-1941}

\section{Résumé}

Au début des années 1920 s'est ouvert au Chili un scénario d'instabilité institutionnelle, découlant de la crise du régime oligarchique et de la consolidation politique des mouvements discriminatoires. Cette crise, qui s'est étendue jusqu'à l'arrivée au pouvoir du Front populaire (1938), s'est élevée à des niveaux croissants de violence, impliquant à la fois des groupes antagonistes et des mouvements idéologiquement proches. Dans cet article, nous analysons les scénarios et les acteurs qui ont façonné les scènes du conflit politique au Chili et nous identifions les dynamiques qu'a acquises la violence.

Mots clés: Instabilité, conflits, violence, mouvements politiques, Le Chili..

\section{INTRODUCCIÓN}

Las principales organizaciones de izquierda en Chile han sido, históricamente, el Partido Comunista de Chile (PCCh, 1922) y el Partido Socialista de Chile (PSCh, 1933). Ambas organizaciones han tenido importantes niveles de adhesión social y política entre diferentes franjas de la población, especialmente entre trabajadores industriales, rurales y mineros, funcionarios públicos (en particular maestros) y entre destacados intelectuales y artistas. Incluso en varios momentos de su dilatada historia ambas organizaciones han concurrido a la formación de alianzas sociales y políticas que han concitado el respaldo de un numeroso electorado, tal es el caso de las campañas presidenciales de 1938, 1942, 1946, 1958, 1964, siendo, probablemente la más importantes de todas ellas la campaña presidencial de 1970, que llevó al poder a Salvador Allende, apoyado por la coalición Unidad Popular.

Es más, socialistas y comunistas impulsaron de manera conjunta importantes movimientos huelguísticos y contribuyeron a formar dos de las más importantes centrales obreras en la historia de los trabajadores chilenos: la Confederación de Trabajadores de Chile (CTCh, 1936) y la Central Única de Trabajadores (CUT, 1953). Como consecuencia de ello han sido objeto, en muchas ocasiones de forma simultánea, de intensas batidas represivas, que han culminado con el asesinato, encarcelamiento 
o exilio de sus militantes y dirigentes. No es extraño, por lo tanto, que en la cultura política de la izquierda chilena se reconozca y reivindique, sin distinciones y exclusiones, a muchos "mártires" de la lucha popular, siendo las figuras más emblemáticas, el presidente Salvador Allende (socialista) y el cantautor popular Víctor Jara (comunista).

No obstante, la historia de ambas colectividades difícilmente podría calificarse de fraterna, tanto a nivel de sus estructuras de dirección (nacionales, regionales y locales), como a nivel de las organizaciones y militantes de base. Muy por el contrario, en las relaciones entre ambas colectividades ha predominado la desconfianza, lo cual se relaciona con la fuerte disputa que han sostenido por la dirección del movimiento de trabajadores ${ }^{1}$. Efectivamente, ambas organizaciones se han definido como la vanguardia de la clase trabajadora, concordante con ello han desarrollado estrategias de control y cooptación del movimiento sindical y, en ese contexto, han desplegado intensas campañas de desacreditación de sus competidores. En varias ocasiones esta conflictividad derivó en hechos de violencia que concluyeron con militantes heridos o asesinados. Estos episodios de violencia profundizaron las desavenencias y los conflictos arraigando al interior de ambas organizaciones posturas de un fuerte antagonismo. En este artículo nos proponemos analizar el contexto histórico de inestabilidad política que se gestó en el país desde comienzos de la década de 1920, situando los diferentes escenarios en que se dio el conflicto y la violencia e identificando a sus protagonistas.

\section{LOS ANTECEDENTES DE LA CONFLICTIVIDAD}

Para entender la conflictividad entre ambas organizaciones es necesario remontarse a las tensiones que acompañaron a la formación y desarrollo de la Federación Obrera de Chile (FOCH). Efectivamente, esta organización obrera se constituyó en 1909 como una sociedad de socorros mutuos, vinculada a los trabajadores ferroviarios y estrechamente ligada a un grupo de dirigentes conservadores, como Pablo Marín Pinuer ${ }^{2}$.

1 Alan Angell, Partidos políticos y movimiento obrero en Chile. De los orígenes hasta el triunfo de la Unidad Popular (México: Ediciones ERA, 1974), 113-115.

2 Mario Garcés y Pedro Milos, FOCH, CTCH, CUT. Las centrales unitarias en la historia del sindicalismo chileno (Santiago de Chile: Educación y Comunicaciones, 1988), 15-19 y Francisca Durán, 
Pero entre 1917 y 1919 la organización comenzó a ser copada por cuadros obreros provenientes del Partido Demócrata (PD, 1887), del Partido Obrero Socialista (POS, 1912) y por militantes anarcosindicalistas $^{3}$. En su III Conferencia, realizada en Concepción en diciembre de 1919, y bajo la conducción del destacado dirigente obrero, Luis Emilio Recabarren, la FOCH se definió como una organización anticapitalista y revolucionaria y, posteriormente, en 1921, se afilió a la Internacional Sindical Roja ${ }^{4}$. Este creciente vínculo de la FOCH con el movimiento bolchevique distanció rápidamente de sus filas a los ácratas, que dieron origen en 1919 a la sección chilena de la International Workers of the World (IWW), a la par que se acentuaba la disidencia de los dirigentes y trabajadores ligados al Partido Demócrata ${ }^{5}$. Estos problemas se hicieron aún más evidentes a partir de enero de 1922 cuando el POS, en el marco del III Congreso de la organización, decidió afiliarse a la Internacional Comunista y transformarse en Partido Comunista de Chile. En esa misma línea, la muerte de su dirigente histórico, Luis Emilio Recabarren (1924), y el ulterior proceso de bolchevización de la organización agudizaron las disputas internas ${ }^{6}$.

"Definiendo rumbos: la FOCH entre la acción sindical y la acción política", Revista Izquierdas Vol. 2 No. 3 (2009): 2-7.

3 El Partido Obrero Socialista, fundado por Luis Emilio Recabarren en 1912, es reconocido como la primera organización revolucionaria de orientación marxista. Al respecto ver, Julio Pinto, "Socialismo y salitre: Recabarren, Tarapacá y la formación del Partido Obrero Socialista", Historia Vol. 32 (1999): 315-366.

4 Crisóstomo Pizarro, La huelga obrera en Chile (Santiago de Chile: Ediciones SUR: 1986), 59-75 y Julio Pinto Vallejos, Luis Emilio Recabarren. Una biografía histórica (Santiago de Chile: LOM Ediciones, 2013), 171-195.

5 Los conflictos de largo aliento entre anarquistas y socialistas en Sergio Grez, Los anarquistas y el movimiento obrero. La alborada de la idea en Chile, 1893-1915 (Santiago de Chile: LOM Ediciones, 2007), 159-177. Respecto de la IWW ver los trabajos de Mario Araya Saavedra, "Los wobblies criollos: Fundación e ideología en la región chilena de la Industrial Workers of the World - IWW (1919 - 1927)" (Tesis de Licenciatura en Historia, Universidad ARCIS, 2008), 40-50 y Camilo Santibáñez, "La IWW y el movimiento obrero en Chile: El caso de los obreros portuarios nortinos (1919-1923)", Diálogo Andino No. 55 (2018): 19-28. Para el caso del Partido Demócrata y en especial su esfuerzo por crear un Partido Laborista, de corte socialdemócrata, en base al POS, la FOCH y el propio PD ver, Jorge Barría Serón, El movimiento obrero en Chile, Síntesis histórico-social (Santiago de Chile: Ediciones de la Universidad Técnica del Estado, 1971), $42-47$ y Sergio Grez, El Partido Democrático de Chile. Auge y ocaso de una organización política popular (1887-1927) (Santiago de Chile: LOM Ediciones, 2016), 261-292.

6 Sergio Grez, Historia del comunismo en Chile. La era de Recabarren (1912-1924) (Santiago de Chile: LOM Ediciones, 2011), 153-170. 
La aprobación de las denominadas "Tesis del Tercer Período" o "Frente Único", en el VI Congreso de la Internacional Comunista (Moscú, 1928), alineó a los partidos comunistas en torno a la política exterior de la Unión Soviética y favoreció una estrategia de enfrentamiento directos tanto con la burguesía como con los partidos socialdemócratas, a las cuales se rotulaba de social-fascistas. Este proceso acentuó las pugnas con quienes, desde otros campos de la izquierda, objetaban el creciente vínculo de dependencia entre el PCCh y el Partido Comunista de la Unión Soviética (PCUS) ${ }^{7}$. Pero también generó nuevas disidencias al interior de la FOCH y del PCCh. Entre estas cabe destacar la liderada por Manuel Hidalgo Plaza y Emilio Zapata Díaz, dos destacados dirigentes comunistas que cuestionaron tanto el centralismo democrático, como la tesis del frente único. Este grupo rompió la unidad partidaria en 1931 al presentar la candidatura presidencial de Manuel Hidalgo y confrontarla con la candidatura oficial de Elías Lafferte Gaviño ${ }^{8}$. Pero los diferendos entre las fracciones no se redujeron a los intercambios de denuestos a través de la prensa, de manera regular los comités de campaña se enfrentaban violentamente en las calles demandando la legitimidad de su respectiva organización y candidato. Así ocurrió el sábado 29 de agosto de 1931, cuando en el acto de proclamación de la candidatura a la Presidencia de la República de Manuel Hidalgo, realizada en el Teatro Nacional de Santiago, irrumpió un grupo de militantes afines a la candidatura de Elías Lafferte y arrojó piedras contra el candidato adversario y sus adherentes. Al respecto una nota del periódico hidalguista La Chispa señalaba:

"En medio de esto, un cobarde lanzó una pedrada desde uno de los balcones de la galería que iba con bastante fuerza al impulso de la distancia, la que fue a pegar en el estómago al compañero Hidalgo, haciéndole palidecer. Los compañeros perdieron la serenidad y subiendo a la galería sacaron como se merecía a los autores de tan ciones presidenciales en Chile, 1931", Historia Vol. 2 No. 48 (2015): 465-503 y Andrew Barnard, "El Partido Comunista de Chile y las políticas del tercer período, 1931-1934", en 1912-2012 El siglo de los comunistas chilenos, eds. Olga Ulianova, Manuel Loyola y Rolando Álvarez (Santiago de Chile: Instituto de Estudios Avanzados, 2012), 115-169. 
cobarde atentado. Hidalgo pronuncio un vibrante discurso que mereció largos aplausos por la concurrencia. Así lucha la camarilla de Contreras Labarca, Lafertte y Cía.”’.

Si bien ambos candidatos obtuvieron muy pobres resultados en dichas elecciones la fractura política favoreció la emergencia de la denominada Izquierda Comunista (1934-1936), la cual se articuló con otras fuerzas de izquierda en torno al denominado Block de Izquierda hasta su disolución en el Partido Socialista en $1936^{10}$.

Sin duda la fundación del Partido Socialista de Chile, en abril de 1933, se convirtió en un importante desafío para los comunistas. El nuevo partido se definía como una organización de trabajadores "manuales e intelectuales", que asumía el marxismo como método de interpretación de la realidad, pero "rectificado y enriquecido" por los aportes científicos y el devenir social, precepto que desafiaba la escolástica stalinista vigente en ese momento. Amparados en el marxismo los socialistas reconocían la existencia de una sociedad escindida en clases sociales antagónicas (burguesía y trabajadores), el carácter opresor del Estado burgués y la existencia de la lucha de clases como motor de la historia. La utopía socialista conllevaba la colectivización de los medios de producción a objeto de alcanzar el socialismo, fase a la cual se accedía a través de una etapa transitoria que denominaban "dictadura de los trabajadores". Por último, se reconocían como internacionalistas y antiimperialistas, pero contrarios a toda sujeción externa, fuera esta socialdemócrata o comunista $^{11}$.

El PS experimentó un crecimiento vertiginoso, especialmente entre la clase obrera, el campesinado, técnicos y profesionales vinculados al

9 "Los últimos acontecimientos revolucionarios afianzan poderosamente la candidatura del camarada Hidalgo", La Chispa, Santiago de Chile, septiembre, 1931, 7.

10 Mariano Vega, "¿Hidalguismo versus lafertismo? Crisis y disputa por la representación del comunismo en Chile, 1929-1933", en 1912-2012 El siglo de los comunistas, 97-114.

11 Julio Cesar Jobet, El Partido Socialista de Chile, vol. 1 (Santiago de Chile: Ediciones Prensa Latinoamericana, 1971), 77-80; Partido Socialista, "Estatuto orgánico", Núcleo, Valparaíso, 1 de agosto, 1934, 3-12 y Partido Socialista, "Programa de acción inmediata del Partido Socialista", Núcleo, Valparaíso, 1 de septiembre, 1934, 24-38. 
aparato del Estado, jóvenes estudiantes y entre el mundo femenino. Muchos de quienes concurrieron a formar las filas del PS provenían de experiencias políticas previas, no solo en aquellas organizaciones que dieron origen al PS, como el Partido Socialista Marxista (PSM), la Nueva Acción Pública (NAP), la Orden Socialista (OS) y la Acción Revolucionaria Socialista (ARS), sino que habían militado en las filas de la FOCH, el POS, la IWW o el PD. Se trataba, por lo tanto, no solo de la amalgama de una serie de tendencias diversas, sino que, además, de culturas políticas heterogéneas, en muchas de las cuales el anticomunismo era un componente fundamental. Por otro lado, el PS no repudiaba la institucionalidad política vigente, lo cual lo situaba en un escenario favorable a objeto de construir una política de masas en los recientemente creados sindicatos legales, a la vez que ampliaba su base social de apoyo por la vía de la participación en los procesos electorales $^{12}$. Por último, el liderazgo socialista temprano se encontraba constituido por sujetos, como Marmaduke Grove, Oscar Schnake y Eugenio Matte, que habían tenido una participación destacada en la lucha contra el régimen autoritario de Carlos Ibáñez del Campo (1927-1931) y en la efímera "República Socialista" de $1932^{13}$.

Las complejidades propias de un escenario severamente afectado por la recesión económica de la década de 1930, unido a la crisis institucional que se arrastraba en el país desde la caída de la dictadura de Ibáñez (1931) y la formación de un escenario de disputa ideológica y política por la conducción del movimiento de trabajadores tras la fundación del Partido Socialista (1933), generaron las condiciones para la irrupción de episodios de violencia que involucraron tanto a los militantes de la izquierda entre sí, como a estos con miembros de bandas armadas de derecha y con el aparato represivo del Estado.

12 Julio César Jobet, El Partido Socialista de Chile, 47-49 y Paul Drake, Socialismo y populismo Chile, 1936-1973 (Valparaíso: Universidad Católica de Valparaíso, 1992), 120-142.

13 Respecto de este ciclo ver, Jorge Rojas, La dictadura de Ibáñez y los sindicatos (1927-1931) (Santiago de Chile: DIBAM, 1993), 143-172 y Luis Cruz Salas, La República Socialista del 4 de junio (Santiago de Chile: Ediciones de la Biblioteca Clodomiro Almeyda, 2012), 41-56. 


\section{LAS DINÁMICAS DEL CONFLICTO}

La crisis del régimen oligárquico, inaugurada hacia fines del siglo XIX con el ascenso del movimiento obrero y con la fractura de las clases dirigentes en torno a la Guerra Civil de 1891, se profundizó a lo largo de las tres primeras décadas de del siglo XX, alcanzando su punto más alto de desarrolló entre 1924 y $1932^{14}$. Efectivamente, el ciclo de movilizaciones populares iniciado con las "marchas del hambre" convocadas por la Asamblea Obrera de Alimentación Nacional (AOAN), en 1918, se extendió hasta 1919, para luego transformarse en movimientos huelguísticos que afectaron a las actividades salitreras, portuarias e industriales ${ }^{15}$. El momento más álgido de este proceso se vivió durante la huelga general que afectó a los cantones salitreros de Tarapacá entre abril y junio de 1925. Este movimiento, inscrito en pleno contexto de crisis de la actividad salitrera, demandaba aumento de salarios y mejores condiciones materiales de trabajo y de vida para los obreros y sus familias, pero a contrapelo de la justicia de sus demandas fue desoído por la administración de Alessandri, la que despachó a la región a unidades del ejército para contener la movilización ${ }^{16}$. El resultado fue un violento enfrentamiento entre trabajadores y militares verificado el 5 de junio de 1925, especialmente en la oficina salitrera de La Coruña, que concluyo (de acuerdo a cifras oficiales), con 59 trabajadores asesinados por el ejército y dos policías y un comerciante muertos a manos de los obreros ${ }^{17}$.

La situación política general no era mucho mejor. La promulgación de una legislación social que atendiera las demandas de los trabajadores, que había sido la punta de lanza de la campaña presidencial de Arturo Alessandri Palma en 1920, había sido desplazada de las prioridades de la agenda parlamentarias, provocando descontento tanto entre los traba-

14 Sofía Correa, Con las riendas del poder. La derecha chilena en el siglo XX (Santiago de Chile: Debolsillo, 2016), 52-68.

15 Peter De Shazo, Trabajadores urbanos y sindicatos en Chile: 1902-1927 (Santiago de Chile, DIBAM, 2007), 215-298.

16 La reestructuración coercitiva del Estado chileno en la primera mitad de la década de 1920 en: Verónica Valdivia, "Los tengo plenamente identificados. Seguridad interna y control social en Chile, 1918-1925”, Historia Vol. 1 No. 50 (2017): 241-271.

17 Rolando Álvarez, “La matanza de La Coruña. Chile, 1925”, Contribuciones Científicas y Tecnológicas No. 116 (1997): 77-108. 
jadores como entre los militares que observaban con preocupación como se agudizaban los enfrentamientos de clase. Ello precipitó una movilización de oficiales jóvenes del ejército en las gradas del Congreso Nacional ("Ruido de Sables" del 3 de septiembre de 1924), que presionaron a los parlamentarios para una rápida evacuación de la legislación social pendiente. Tras este acontecimiento los militares obligaron al Presidente de la República a dejar el poder y salir del país (11 de septiembre de 1924), para luego restablecerlo en el mismo (marzo de 1925), pero ya como un mero administrador de las decisiones que adoptaban los militares. Es en este contexto en el cual se promulgó la Constitución Política de 1925 que dio origen a un régimen político presidencialista, que dotó al Estado de crecientes atribuciones en materia de intervención económica y social. No obstante, el nuevo proceso institucional no resolvió la crisis del sistema oligárquico, por el contrario, esta crisis se extendió a lo largo de todo este ciclo, relevando cada vez más la activa incidencia de los militares en la administración del sistema político. De hecho, Carlos Ibáñez del Campo se mantuvo como primera figura política durante las breves administraciones de Luis Barros Borgoño y Emiliano Figueroa (1925-1927), para posteriormente asumir directamente el poder el 21 de julio de $1927^{18}$.

Los militares liderados por Ibáñez asumían que la estabilidad del sistema político y por extensión del Estado, pasaba por incorporar algunas demandas obreras, lo cual, a su vez, conllevaba neutralizar las resistencias oligárquicas y aplastar a los sectores más radicales del movimiento de trabajadores. No es extraño, por lo tanto, que uno de los rasgos distintivos de la primera administración de Carlos Ibáñez del Campo (19271931), haya sido el uso extendido de la represión estatal, expresada como prohibiciones de huelgas y manifestaciones, confinamiento de los dirigentes sindicales y políticos más destacados y uso extendido de la tortura en cuarteles policiales ${ }^{19}$. No obstante, Ibáñez también estimuló la sindicalización de aquellos trabajadores que no formaban parte ni de

18 Felipe Portales, Los mitos de la democracia chilena. Vol. II desde 1925 a 1938 (Santiago de Chile: Editorial Catalonia, 2010), 34-57 y Jorge Rojas, La dictadura de Ibáñez, 13-21.

19 Ximena Urtubia, Hegemonía y cultura política en el Partido Comunista de Chile. La transformación del militante tradicional (1924-1933) (Santiago de Chile: Ariadna Ediciones, 2017), 126-137 y Jorge Rojas, La dictadura de Ibáñez, 23-45. 
la FOCH, ni de la IWW, los cuales, a su vez, contaron con el apoyo de la burocracia estatal a objeto de insertarse en la reciente legislación social. Expresión de ello fue la Confederación Republicana de Acción Cívica de Obreros y Empleados de Chile (CRAC), fundada en 1929. Muchos de estos trabajadores provenían de las antiguas disidencias incubadas al interior de la $\mathrm{FOCH}$, por lo cual asumieron como una alternativa de organización social y política la propuesta ibañista y, además, respaldaron su política de persecución de los sindicatos y partidos revolucionarios $^{20}$. Hacia comienzos de la década de 1930 el gobierno de Ibáñez, severamente afectado por la crisis económica desencadenada en 1929, y carente de apoyos sociales y políticos sólidos tanto entre las élites dirigentes como entre los trabajadores, sucumbió frente a la movilización social renunciando al cargo de Presidente de la República, el 26 de julio de 1931, y exiliándose en Argentina.

Tras la caída de Ibáñez se gestó una fase de gran inestabilidad política, la que se extendió hasta la llegada al gobierno (por un segundo período presidencial), de Arturo Alessandri Palma. En esta fase, que va desde el 26 de julio de 1931 hasta el 24 de diciembre de 1932, se sucedieron 8 jefes de gobierno en 17 meses calendario, lo que pone de manifiesto que las clases dirigentes eran incapaces de sancionar un nuevo pacto de gobernabilidad, mientras que los sectores populares carecían de la fuerza suficiente y la unidad necesaria para tomar el poder ${ }^{21}$. En este contexto se desarrollaron una serie de incidentes en los cuales no estuvo ausente la violencia. Uno de los más graves fue el denominado "levantamiento de la marinería" que se desarrolló entre el 31 de agosto y el 7 de septiembre de 1931. En esa ocasión los tripulantes de la flota de guerra y los marinos acantonados en las bases navales de Coquimbo, Valparaíso y Talcahuano se tomaron sus puestos de combate, como manifestación de rechazo a la iniciativa del gobierno de reducir los salarios de los empleados públicos. Durante el levantamiento, que fue violentamente reprimido por el ejército, recibieron la adhesión del Partido Comunista y de la FOCH. Varias decenas de marinos murieron en los

20 Jorge Rojas, La dictadura de Ibáñez, 124-130.

21 Los gobernantes fueron: Pedro Opaso Letelier, Juan Esteban Montero Rodríguez, Manuel Trucco Franzani, nuevamente Juan Esteban Montero, Arturo Puga Osorio, Carlos Dávila Espinoza, Bartolomé Blanche Espejo y Abraham Oyanedel Urrutia. 
enfrentamientos con el ejército y los demás fueron sometidos a consejo de guerra y más tarde amnistiados por el gobierno de Carlos Dávila en $1932^{22}$.

Tres meses más tarde un nuevo hecho de violencia afectaba al país, en esta ocasión en la provincia de Atacama. La madrugada del 25 de diciembre un grupo de trabajadores pertenecientes a la FOCH, apoyados por soldados, intentaron infructuosamente tomar el control del cuartel en el que se encontraba apostado un batallón del regimiento Esmeralda en Copiapó. El ataque, del cual tenían conocimiento las autoridades castrenses, fue repelido y, posteriormente, sus perpetradores fueron perseguidos y asesinados sumariamente. La represión militar se extendió hasta la vecina ciudad de Vallenar donde, al igual que en Copiapó, varios militantes obreros fueron asesinados ${ }^{23}$.

El punto más alto de estas asonadas revolucionarias fue el levantamiento cívico-militar del 4 de junio de 1932, liderado por el comodoro del aire Marmaduke Grove. Ese día, Grove, junto al general Arturo Puga, los dirigentes socialistas Oscar Schnacke y Eugenio Matte y el abogado ibañista Carlos Dávila, movilizaron a unidades militares de la base aérea de El Bosque y a simpatizantes de la NAP y del PSM en dirección del palacio presidencial de La Moneda, logrando precipitar la renuncia al gobierno de Juan Esteban Montero. El nuevo régimen, que se autoproclamó como "República Socialista", clausuró el "Congreso Termal" que Ibáñez había hecho elegir en 1930, condonó las deudas contraídas por la población ante la Caja de Crédito Prendario, suspendió los lanzamientos de arrendatarios morosos y amnistió a los prisioneros políticos. No obstante, la composición heterogénea del movimiento constituía su mayor debilidad y fue ella la que permitió que Carlos Dávila desalojara del gobierno a los socialistas y le imprimiera un giro conservador al proceso. Eso hasta su propia destitución, la que se produjo el 13 de

22 En relación con el levantamiento de la marinería ver: Jorge Magasich, Los que dijeron No. Historia del movimiento de los marinos antigolpistas de 1973, vol. 1 (Santiago de Chile, LOM Ediciones, 2008), 149-187 y William F. Sater, "The abortive Kronstadt: The chilean naval mutiny of 1931", The Hispanic American Historical Review Vol. 60 No. 2 (mayo 1980): 239-268.

23 Verónica Valdivia, "El ocaso del salitre: Navidad en Copiapó y Vallenar. Chile, 1931”, Boletín del Instituto de Historia Argentina y Americana "Dr, Emilio Ravignani” Tercera Serie No. 19 (1 semestre 1999): 81-114. 
septiembre de $1932^{24}$. Para los comunistas chilenos el movimiento liderado por Grove era una maniobra putschista del social fascismo chileno, que solo confundía y desarmaba a las masas ${ }^{25}$.

La crisis de gobernabilidad, inaugurada hacia 1924, solo comenzó a resolverse con el regreso de Arturo Alessandri Palma al poder en diciembre de 1932. Alessandri obtuvo en las elecciones presidenciales de octubre de ese año un $55 \%$ de los votos, imponiéndose de forma contundente a todos sus competidores. Pero en esta ocasión, y a diferencia de lo ocurrido en 1920, el gobierno de Alessandri se orientó, claramente, por una política conservadora, que restringió el gasto público, a objeto de hacer frente a la recesión económica, que pretendió limitar la capacidad de movilización de los trabajadores, a la par que intentaba reducir la influencia política de los militares y, por esa vía, restablecer la gobernabilidad en el país ${ }^{26}$.

La agudización de los enfrentamientos políticos y, junto con ella, de la situación de inestabilidad, gestó las condiciones para la imposición de una serie de normativas que buscaban restablecer el orden público y la seguridad del Estado. Concordante con ello se dictó, el 6 de mayo de 1931, el Decreto con Fuerza de Ley $\mathrm{N}^{\circ} 143$, que castigaba con la pena de extrañamiento a quienes propagaran noticias falsas ${ }^{27}$. Pocos después, una vez defenestrada la "República Socialista", el gobierno de Carlos Dávila dictó el Decreto Ley N 50, de 24 de junio de 1932, que identificaba y sancionaba una serie de actos políticos, como propagar doctrinas que tuvieran como objetivo destruir el orden social y la organización política del Estado o asociarse en función de dichos objetivos, como conductas terroristas. En este segundo caso la normativa establecía

24 Luis Cruz Salas, La República Socialista, 41-56.

25 El conflicto entre la República Socialista y el Partido Comunista aparece relatado en Jorge Grove, Descorriendo el velo. Episodio de los doce días de la República Socialista (Santiago de Chile: Folleto, Valparaíso, 1933), 24-26. La postura crítica de los comunistas chilenos frente a la República Socialista en, Andrew Barnard, El Partido Comunista de Chile, 1922-1947 (Santiago de Chile: Ariadna Ediciones, 2017), 100. Las polémicas entre comunistas y socialistas respecto de la República Socialista se continuaban manifestando en el ciclo "unitario" de 1936. Ver, al respecto, Julio Balmaceda, "El 4 de junio y los comunistas", Consigna, Santiago de Chile, 4 de junio, 1936, 6.

26 Julio Faundez, Democratización, desarrollo y legalidad. Chile, 1831-1973 (Santiago de Chile: Universidad Diego Portales, 2011), 97-99 y Felpe Portales, Los mitos de la democracia, 203-374.

27 Estado de Chile, "Decreto con fuerza de Ley N 143", Santiago de Chile 6 de mayo (1931). 
diferentes penas de presidio para los responsables ${ }^{28}$. Cerró este ciclo la dictación de la Ley $\mathrm{N}^{\circ} 3.026$ sobre Seguridad Interior del Estado, de 12 de febrero de 1937. El extenso texto, de 25 artículos y múltiples incisos, tipificaba una serie de conductas como delitos políticos, entre otros, incitar a la subversión o a la rebelión, asociarse para destruir el orden social, político y jurídico, ultrajar la bandera o edificios públicos, promover y mantener huelgas destinadas a subvertir el orden público, etc. Una preocupación especial del legislador apuntó a contener la formación de estructuras paramilitarizadas que amenazaran la estabilidad del sistema político. A ese efecto se señalaba:

"Por ser contrarias a las bases fundamentales del orden constituido y jurídico de la República, se prohíbe la existencia u organización en Chile de todo movimiento, facción o partido militarizado o uniformado que persiga la implantación en la República de un régimen opuesto a la democracia [...] Queda prohibido el uso de banderas, emblemas, uniformes o signos de carácter disolvente o revolucionario. La fuerza pública procederá a disolver todo desfile, reunión o manifestación en que se usen algunos de los signos o distintivos indicados en este artículo"29.

Efectivamente, en el marco de la crisis política que desembocó en la creación de la "República Socialista" sujetos provenientes de la pequeña burguesía comercial y profesional, antiguos militares en retiro, militantes de la Unión Republicana y adherentes de las organizaciones políticas tradicionales (conservadores, liberales y radicales), dieron origen, el 24 de junio de 1932, a la Milicia Republicana. Una organización paramilitar, de extensión nacional, compuesta de aproximadamente 80.000 civiles armados, cuyo objetivo principal era impedir que los militares volvieran al poder. Esta organización, que contó con el respaldo de la administración de Arturo Alessandri Palma, desarrollaba cursos de instrucción física y militar, realizaba demostraciones públicas a través de desfiles y acuartelamientos y sus integrantes se veían regularmente involucrados

29 Estado de Chile, "Ley N ${ }^{\circ} 3.026$ ", Santiago de Chile 12 de febrero (1937). 
en golpizas a militantes obreros y de organizaciones de izquierda ${ }^{30}$. Así lo indica la prensa obrera del período:

"Los miembros de la Milicia Republicana de este puerto obedeciendo fielmente a sus consignas de defender los intereses del capitalismo y balear al roto, se han entregado de lleno a su innoble tarea, seguros de quedar impunes de todos los delitos, atropellos y vejámenes que cometan. El compañero Florencio Espinoza, miembro del Sindicato de estibadores de este puerto, ha sido la primera víctima que ha caído herido bajo las balas del miliciano Enrique Navarrete quien, sin ningún escrúpulo, de ninguna naturaleza, le disparó tres tiros de pistola por la espalda, dando uno de ellos en una pierna, en circunstancias, que este obrero se dirigía tranquilamente a su casa después de sus labores diarias" $"$.

En esta misma línea de paramilitarización de la política se inscribe la fundación, el 5 de abril de 1932, del Movimiento Nacional Socialista de Chile (MNSCh), mejor conocidos como "naci". Esta organización, compuesta mayoritariamente por profesionales, estudiantes universitarios y exmilitares, abogaba por el restablecimiento de la autoridad a través de un gobierno nacional fuerte, que garantizara el orden, la jerarquía y la justicia social ${ }^{32}$. El movimiento creó en 1933 una sección que denominó “Tropas Nacistas de Asalto" (TNA), las cuales tenían como objetivo limpiar las calles de la presencia de anarquistas y marxistas. Su crecimiento, entre diferentes sectores sociales, tanto de élite como populares, fue considerable, logrando un importante arraigo en Santiago, Valparaíso, Concepción y Temuco ${ }^{33}$.

30 Verónica Valdivia, La Milicia Republicana, Los civiles en armas, 1932-1936 (Valparaíso: Editorial América en Movimiento, 2016), 75-97. Concebida como una organización surgida frente a la situación de desgobierno existente en el país y por lo tanto transitoria, la Milicia se autodisolvió el 3 de julio de 1936. La autoridad y la gobernabilidad ya se encontraba restauradas.

31 Unión Sindical de ex y Obreros de Arsenales de la Marina, "Balas asesinas", El Socialista, Concepción, segunda quincena de abril, 1934, 1.

32 Daniel Venegas, "La concepción nacista de la sociedad: Posición doctrinaria en torno al sujeto del cambio y las organizaciones de trabajadores", Revista de Historia Vol. 1 No. 26 (2019), 59-82.

33 Marcelo Bonnassiolle, "A ganar las calles y cambiar la nación. Conflictividad social, violencia y represión estatal en la lucha antifascista y antimarxista en Chile, 1932-1938" (Tesis de Maestría en Historia, Universidad de Santiago de Chile, 2016), 96-110. 
A partir de la formación del MNSCh, y en especial de las TNA, los incidentes violentos con militantes de izquierda se comenzaron a multiplicar. Uno de los más importantes se produjo en Santiago el 6 de agosto de 1933 con ocasión de la realización del primer acto público de los nacis chilenos. En esa oportunidad el MNSCh se reunió en el teatro Providencia, en pleno centro de la ciudad, y hasta el lugar llegaron también contra manifestantes de izquierda, iniciándose un violento enfrentamiento entre ambas partes ${ }^{34}$. Estos incidentes se hicieron recurrentes a lo largo de todo el período analizado, en especial en centros universitarios y en espacios públicos a los cuales se concurría a objeto de apoyar mítines políticos ${ }^{35}$. No obstante, también se hizo habitual el que en espacios de ingesta etílica (bares, tabernas, festividades, etc.), las diferencias políticas se exteriorizaran y ellas llevaran a violentos enfrentamientos. Esto le correspondió experimentar al militante nacionalsocialista Pablo Acuña que murió apuñalado en septiembre de 1936, en una fonda, en el marco de las celebraciones de Fiestas Patrias. De acuerdo con lo informado por la prensa naci, Acuña habría gritado: "iViva el nacismo!", tras lo cual habría sido agredido por un grupo de obreros presentes en el lugar ${ }^{36}$.

El ocaso del MNSCh y de sus TNA se produjo en octubre de 1938 cuando la agrupación intento llevar a cabo un golpe de Estado para deponer al Presidente Arturo Alessandri, obligar a los militares a tomar el control del gobierno y restablecer en el poder a Carlos Ibáñez del Campo. La sonada golpista fracasó, los militantes del MNSCh que había ocupado la casa central de la Universidad de Chile y las dependencias del edificio del Seguro Obrero fueron obligados a rendirse y una vez

34 "Nacistas y comunistas sostuvieron ayer varios encuentros a bofetadas, pedradas y balazos", La Nación, Santiago de Chile, 7 de agosto, 1933, 6.

35 "Estudiantes izquierdistas repelen a los nacistas", Consigna, Santiago de Chile, 30 de mayo, 1936, 1.

36 "Homenaje a Pablo Acuña rindieron el 19 las T.N.A.", Trabajo, Santiago de Chile, 22 de septiembre, 1936, 1. Algo similar ocurrió en la localidad de Illapel, el 14 de octubre de 1938, cuando en pleno centro de la ciudad, a la salida del bar del Hotel Alemán, fue asesinado el Presidente del Frente Popular de Illapel, el dentista radical Bernardo Ross Peña. Sus ejecutores formaban parte de la comitiva del diputado conservador Rafael del Canto. "Agentes rossistas, con almas de chacales, asesinaron antenoche alevosamente, al prestigioso profesional Dn. Bernardo Ross Peña”, El Reflector, Illapel, 16 de octubre, 1938, 1 y 4. 
concentrados en el segundo edificio fueron ejecutados por la policía de carabineros $^{37}$.

La izquierda chilena no escapó a esta tendencia a la militarización de la política y a desarrollar una disposición favorable al uso de la violencia. Pero, mientras en el caso del PCCh se privilegió el despliegue de los militantes sindicales y de los cuadros adscritos a la Federación Juvenil Comunista (FJC), en el caso de los socialistas se optó por formar una estructura paramilitar ${ }^{38}$. Los gérmenes de la misma fueron las Brigadas de Defensa, formadas hacia 1934, que posteriormente (febrero de 1938), pasaron a denominarse Milicias Socialistas (MS ${ }^{39}$. Estas estructuras se constituyeron con el propósito de frenar el avance de las bandas armadas de la derecha y del fascismo, pero también para afianzar la posición del Partido Socialistas como alternativa de poder ${ }^{40}$. Las estructuras paramilitares del PSCh tuvieron especial éxito en la protección de las "casas del pueblo" y la defensa de las manifestaciones desarrolladas por los trabajadores, pero también jugaron un rol relevante en la lucha de tendencias al interior de la organización ${ }^{41}$. Efectivamente, el mando de las Milicias siempre estuvo directamente relacionado con la estructura de dirección del Partido, de manera que cuando se confi-

37 El estudio de Marcelo Bonnassiolle (A ganar las calles, 133-146), señala que 59 militantes del MNSCh y dos funcionarios del Seguro Obrero fueron asesinados por carabineros.

38 Manuel Loyola, "La Federación Juvenil Comunista (1931-1934)", en Un trébol de cuatro hojas. Las Juventudes Comunistas de Chile en el siglo XX, eds. Rolando Álvarez y Manuel Loyola, (Santiago de Chile: Ariadna Ediciones y Editorial América en Movimiento, 2014), 38-54.

39 Para muchos militantes socialistas la violencia era un instrumento político legítimo, tanto para la defensa de la organización como para la conquista del poder. Así se exponía en una columna de opinión de 1934: "La conciencia revolucionaria no se adquiere con tolerancia para los enemigos que no la tienen con nosotros, ni con el electoralismo burgués, sino en la lucha consciente que es la conquista de un mundo mejor que para conseguirlo no se hará con líricas declaraciones, sino con los hechos. En pocas palabras, preparémonos no sólo para la defensa, sino también para el ataque". Antonio Marzano, "Para la defensa y para el ataque", Núcleo, Valparaíso, 23 de diciembre, 1934, 1.

40 Verónica Valdivia, "Las Milicias Socialistas, 1934-1941", Mapocho. Revista de Humanidades y Ciencias Sociales, No. 33 Primer Semestre (1993): 157-180 y Partido Socialista, Estatutos de las Milicias Socialistas (Santiago de Chile: Imprenta Darricarrere, 1938), 8-15. Las intervenciones parlamentarias de los dirigentes socialistas entregan múltiples antecedentes respecto de las agresiones de las que eran objeto en sus giras por el país. Estas agresiones eran utilizadas como argumento que justificaba la política de autodefensa; ver: Marmaduke Grove, "Jira al norte y manifestaciones públicas", Núcleo, Valparaíso, 1 de noviembre, 1934, 23-29.

41 Uno de los mártires del socialismo en esta época fue Manuel Bastías Acevedo, integrante de las Brigadas de Defensa de Concepción, asesinado a balazos en esa ciudad, por miembros de las Tropas de Asalto nacis el 13 de octubre de 1935. “'Contra el nacismo asesino!”, Consigna, Santiago de Chile, 19 de octubre, 1935, 1 y 4. 
guraba una disidencia interna las Milicias eran regularmente utilizadas para aplastar a los opositores. En 1939 se había formado al interior del PSCh la tendencia "Inconformista", liderada por el profesor César Godoy Urrutia, la que hacia comienzos de 1940 mantenía fuertemente tensionado al PS. En abril de ese año uno de los dirigentes "inconformistas", Pablo López, miembro del comité central del Partido, fue asesinado a tiros por integrantes de la Milicia Socialista. Respecto de este funesto suceso el periódico Consigna del PSCh señaló:

"En momento en que se encontraba reunido el Comité C. [Central] Ejecutivo, realizando su sesión ordinaria de los días miércoles, tuvo la dolorosa noticia de un incidente sangriento provocado en la Seccional $2^{\circ}$ Comuna (Eugenio Matte) por elementos afectos al movimiento denominado "inconformistas" que acaudilla el deputado Cesar Godoy Urrutia, y, además, por algunos elementos provocadores, ajenos al partido. Los dirigía el militante Pablo López quien agredió al secretario seccional, militante Fernando Rosales, pretendiendo erigirse en el Jefe de dicha seccional, lo que determinó un incidente desgraciado a raíz del cual encontró la muerte dicho militante, siendo heridos varios otros" ${ }^{" 42}$.

Este asesinato precipitó la salida de los inconformistas, que formaron el Partido Socialista de Trabajadores (PST), el que en 1944 se disolvió, pasando sus militantes a formar parte del PCCh, mientras que las MS, heridas de muerte por este incidente, terminaron disolviéndose a fines de $1941^{43}$.

Otro fenómeno en el cual la conflictividad política escaló hacia situaciones violentas fue la conflictividad social. Durante este ciclo la misma estuvo asociada a los efectos que la recesión económica tuvo entre la población y, en particular, entre los trabajadores urbanos y rurales. Efectivamente, los niveles de desocupación se amplificaron significativamente a la par que se precarizaban las condiciones materiales de vida

42 "Declaración del Comité Central del Partido Socialista", Consigna, Santiago de Chile, 20 de abril, $1940,1$.

43 Julio César Jobet, El Partido Socialista de Chile, 139-143 y Verónica Valdivia, "Las Milicias Socialistas", 177-178. 
de la población ${ }^{44}$. Estas variables estructurales, al superponerse con situaciones de coyuntura, gestaban dramáticas consecuencias para los trabajadores.

Hacia comienzos de 1934, en el valle cordillerano de Lonquimay se incrementó el contexto de expoliación de que eran objeto tanto los trabajadores de lavaderos de oro del río Biobío, como los campesinos mapuches de la zona, a manos de los establecimientos comerciales (pulperías), insertos en las grandes haciendas del sector. Mientras los precios de los productos de primera necesidad se encarecían, sostenidamente los ingresos de los trabajadores quedaban expuestos a la devaluación inflacionaria que campeaba en ese momento el país. En el caso del campesinado mapuche la percepción de abuso se veía acentuada por el despojo de tierras en beneficio de colonos extranjeros que el Estado chileno había patrocinado entre 1881 y $1914^{45}$. Los trabajadores e indígenas, agrupados en torno al Sindicato de Trabajadores Agrícolas de Lonquimay, resistieron las exacciones establecidas por la pulpería, protegieron a los obreros que asaltaron estos establecimientos y apoyaron a los trabajadores agrícolas que estaban siendo expulsado de los fundos de la zona, todo ello en condiciones climáticas adversas ya que los acontecimientos se precipitaron a comienzos del invierno de 1934. La llegada de fuerzas policiales y militares a la región, a mediados de junio, que iniciaron una inmediata batida represiva, precipitó el levantamiento popular a fines de ese mismo mes. Tras una serie de escaramuzas y de asaltos a las haciendas de la región, los enfrentamientos entre trabajadores precariamente armados y las fuerzas policiales y militares del Estado culminaron el 6 de julio de 1934 con la derrota total de los sublevados. Los cálculos oficiales cifran el número de muertos en 150, pero la memoria oral de los habitantes de la zona los fija en más de 500, la mayoría de ellos asesinados después de haberse rendido ${ }^{46}$. Si bien

44 Manuel Marfán, "Políticas reactivadoras y recesión externa: Chile 1929-1938”, Estudios CIEPLAN No. 12 (1984): 89-119.

45 En relación con este episodio, y en especial con la influencia del Partido Comunista en el mismo, ver Olga Ulianova, "Levantamiento campesino de Lonquimay y la Internacional Comunista", Estudios Públicos No. 89 (2003): 173-223. Un análisis más pormenorizado de los acontecimientos en Eduardo Tellez et al, "El levantamiento del alto Biobío y el soviet y la república araucana de 1934", Anales de la Universidad de Chile No. 13 sexta serie (2001).

46 Jaime Flores, "Un episodio en la historia social de Chile 1934, Ranquil: Una revuelta campesina" 
los socialistas chilenos no tuvieron una participación directa en estos acontecimientos su prensa señaló con precisión a los responsables de la matanza:

"Los trabajadores manuales e intelectuales saben demasiado que, cuando fracasan las argucias curialescas y nada pueden las rabulerías de la ley puestas al servicio de los poderosos, los regímenes burgueses enfilan sus carabinas hacia la pobre carne trabajadora y matan, asuelan, devastan y asesinas sin que siquiera un escrúpulo o remordimiento muerdan los corazones de los que así lo ordenaron. No ignoran los proletarios que los regímenes de la Constitución y la Ley, aquellos del amor fecundo y el respeto a todos los derechos - masacres de San Gregorio, de Vallenar, de la FOCH y de Lonquimay- son los que se ensañan más con el proletariado y responden con la metralla a sus peticiones de justicia, a sus voces de dolor a sus clamores de hambre y de abandono" 47 .

No obstante, la profunda derrota del movimiento de trabajadores en Lonquimay, los acontecimientos de 1934 permitieron la definición y puesta en desarrollo de la política agraria del Partido Comunista, a la par que favoreció la formación de la Liga de Campesinos Pobres estimulada por el Partido Socialista ${ }^{48}$.

Hacia mediados de la década de 1930 la situación del movimiento de trabajadores era particularmente compleja. La recesión económica había colapsado al sector salitrero y, junto con ello, a uno de los componentes más relevantes del movimiento obrero clasista, los trabajadores del salitre. Por otro lado, las políticas represivas adoptadas por los diferentes gobiernos del periíodo, en especial el de Carlos Ibáñez del Campo, habían debilitado severamente a las corrientes más radicales. Por último, el sindicalismo legal, heredero de la legislación social de 1924

(Tesis de Maestría en Historia, Universidad de Santiago de Chile, 1993), 71-138.

47 "Otra matanza", Consigna, Santiago de Chile, 7 de julio, 1934, 3. De la misma manera el senador socialista Marmaduke Grove denunció la violencia del actuar policial en Lonquimay ante el Congreso Nacional: Mamaduke Grove, "Sobre la situación política", Núcleo, Valparaíso, 1 de septiembre, $1934,10-21$.

48 Sobre este tema ver, Nicolás Acevedo, Un fantasma recorre el campo. Comunismo y politización campesina en Chile (1935-1948) (Valparaíso: Editorial América en Movimiento, 2017), 9-44 y, del mismo autor, "Autonomía y movimientos sociales. La Liga de Campesinos Pobres y la izquierda chilena (1935-1942)", Revista Izquierdas No. 23 (2015): 44-65. 
había iniciado un rápido desarrollo, profundizando el aislamiento de las corrientes revolucionarias que se mantenían al margen del mismo ${ }^{49}$. No es extraño, en consecuencia, que el movimiento obrero clasista se encontrara dividido en tres tendencias principales: La antigua FOCH, liderada por el PCCh, que al adscribir a las "tesis del tercer período", rechazaba no solo los sindicatos legales, sino que incluso a todas las desviaciones "social fascistas" representadas en las otras corrientes obreras; la Confederación General del Trabajo (CGT, 1931), de orientación anarcosindicalista, que reivindicaba la acción directa de los trabajadores pero que se encontraba muy debilitada; y la Confederación Nacional Sindical (CNS, 1934), de tendencia socialista y anclada preferentemente en el sindicalismo legal. En un escenario de esta naturaleza los conflictos entre sindicalistas y militantes revolucionarios y, subsecuentemente, los hechos de violencia entre los mismos eran frecuentes ${ }^{50}$. Las diferencias y recelos se fundaban tanto en las opciones ideológicas explicitadas, como en las precisiones estratégicas establecidas y, mucho más, en los anatemas construidos respecto de las trayectorias políticas de los adversarios $^{51}$. Para el periódico socialista Consigna cada grupo de izquierda se reconocía como el portador del diseño político correcto y, a partir del mismo, como la mejor guía para conducir al proletariado a la consecución de sus objetivos. Por otra parte, el personalismo, no solo hacía que algunos se erigieran como los "campeones" de la causa proletaria, sino que transformaba a las izquierdas en refugio de "desechos" de todos los regímenes y de todos los partidos ${ }^{52}$. No obstante, el eje más importante de la disputa, entre 1933 y 1935, fue la participación de los trabajadores en los sindicatos legales. En relación con este aspecto la

49 Mario Garcés, Mario Garcés y Pedro Milos, FOCH, CTCH, CUT, 49-51; Jorge Barría Serón, El movimiento obrero en Chile, 87-92; Alan Angell, Partidos políticos y movimiento obrero, 93-129.

50 Leopoldo Benavides, La formación de la izquierda chilena. Relaciones entre el Partido Comunista y el Partido Socialista. Los antecedentes históricos (Santiago de Chile: Documento de Trabajo FLACSO No. 389, 1988), 1-8.

$51 \mathrm{Al}$ conmemorar el segundo año de la fundación del PS un dirigente de dicho partido objetaba a los comunistas por su "táctica histérica y exhibicionista", por pelear más con los "compañeros que con el enemigo", por "olvidar que el marxismo no es un dogma", para concluir: "[...] ante la incapacidad política y revolucionaria del Partido Comunista, nació el Partido Socialista". Eduardo Ugarte, "El camino del combate y la victoria", Consigna, Santiago de Chile, 10 de abril, 1935, 3.

52 "La disolución de las izquierdas y el Partido Socialista", Consigna, Santiago de Chile, 19 de marzo, $1934,3$. 
FOCH levantaba, en 1934, una ácida crítica contra los dirigentes de la Izquierda Comunista y del Partido Socialista:

"Hidalgo formando parte de la asamblea de notables convocado por Montero, y Carlos A. Martínez formando parte del gabinete mismo de Montero, que ametralló a sangre y fuego la lucha de los marineros por sus reivindicaciones. Dávila, Grove los perseguidores de la clase obrera. Esta pandilla de asesinos, de agentes de Guggenheim, del National City Bank, de los banqueros de Londres y de los explotadores nativos son los que han de dar PERSONALIDAD A VUESTROS SINDICATOS. Obreros LA FEDERACIÓN OBRERA DE CHILE os llama a repudiar esta humillación a la dignidad proletaria y sus organizaciones [...] Los sindicatos autónomos, los dirigidos por los jefes socialistas, anarcosindicalistas e hidalguistas tratan de engañar a la clase obrera aparentando repudio al Código del trabajo, pero en la realidad toda su política está supeditada a la colaboración y a1 cumplimiento de las disposiciones del Código, frenan las huelgas y cuando estas estallan la sabotean y la someten a la dictadura de los tribunales del trabajo" ${ }^{23}$.

No puede sorprender, en consecuencia, que los socialistas criticaran duramente los llamados a la unidad que formulaban los comunistas, ya que lo consideraban un gesto hipócrita que escondía el verdadero interés de los comunistas, que no era otro que tomar el control de las organizaciones sindicales. Para la prensa socialista, ni la FOCH ni el PCCh eran prenda de garantía para la unidad y mucho menos para el triunfo de la clase trabajadora, por el contrario, solo "malograban" sus acciones de masas y su espíritu revolucionario ${ }^{54}$. Los socialistas también denunciaban el reformismo y la demagogia de radicales y demócratas, a los cuales consideraban como militantes de partidos en descomposición, preocupados de las prebendas del poder y ajemos a los intereses y preocupaciones de los trabajadores.

53 FOCH, Hagamos la unidad de todos los obreros del país para luchar contra el hambre y la reacción (Santiago de Chile: FOCH, 1934), 5-6.

54 “Unidad obrera?”, Consigna, Santiago de Chile, 16 de junio, 1934, 6 y "Frente a la reacción”, Consigna, Santiago de Chile, 7 de septiembre, 1935, 3. 
"Con olvido total de las doctrinas que dicen sustentar, aliados con los enemigos del pueblo, al que afirman defender, se han prestado para un barrido como para un fregado. Ungida por ellos preside por tercera vez al país una tiranía nepotista disfrazada de civilismo y constitucionalidad; con los votos de ellos, salvo contadas excepciones se han aprobado y entrado a regir las llamadas "Facultades Extraordinarias"; con la firma de algunos de ellos aparece refrendado el Decreto Ley 50; y para no ir demasiado lejos en el recuerdo de su línea sinuosa y zigzagueante, con el caluroso apoyo de ellos se entronizó en el gobierno del país la dictadura de Ibáñez. ¿Para qué seguir enumerando si los nuestros saben, por ejemplo, que en los decretos en los que se los expulsa, se les veja y se les arroja al hambre y la desesperación llevan invariablemente la firma de un ministro radical o han sido aconsejados por un funcionario demócrata?" 55 .

Pero estas disputas no se agotaban en el conflicto que enfrentaba a comunistas y socialistas; otros actores políticos también aparecían recurrentemente en el debate. El Partido Demócrata, que aún mantenía un fuerte ascendente entre los trabajadores agrupados en las sociedades de socorros mutuos, era fuertemente cuestionado desde las filas del socialismo, bajo la acusación de convertir los salones de sus sedes en "garitos", donde se expendían "bebidas alcohólicas", se realizaban "bailes" y se medrada de los salarios de los trabajadores a través de juegos de azar. ${ }^{56}$ En el mismo plano se deben situar las disputas entre socialistas y radicales socialistas por el drenaje de militantes:

"La izquierda socialista tampoco mira con buenos ojos la actuación de nuestro partido y ha habido quienes, han sumado su acción de roedores, a nuestros amigos de la derecha, para llevarse hombres y asambleas a su redil [...] Sepan los roedores, que despectivamente nos llaman ibañistas, que en nuestro Partido no existe individualismos, que asfixian y matan toda idea generosa. Somos sencillamente Radicales-Socialistas" 57 .

55 Diógenes, "Reformismo y demagogia", Jornada, 24 de noviembre, 1934, 3. Ver, también, "Revolucionarios que no lo son", Consigna, Santiago de Chile, 30 de junio, 1934, 3.

56 "Es un inmundo y asqueroso garito el Partido demócrata de Concepción", Consigna, Santiago de Chile, 5 de octubre, 1935, 4.

57 "Nuestra posición", El Radical Socialista, Santiago de Chile, 30 de noviembre, 1933, 3. 
A pesar de este complejo escenario el movimiento de trabajadores avanzó lenta pero sostenidamente hacia crecientes niveles de unidad social y política. Uno de los actores más relevantes en este proceso unitario fue el gremio de los trabajadores de ferrocarriles. ${ }^{58}$ Efectivamente, los trabajadores de la empresa ferroviaria del Estado protagonizaron dos movimientos huelguísticos (enero de 1935 y febrero de 1936) que, por una parte, precipitaron la reacción represiva del Estado (establecimiento del estado de sitio, militarización del sistema ferroviario y detenciones y confinamientos de dirigentes sociales y políticos) y, por la otra, estimularon la solidaridad y el acompañamiento de los restantes sindicatos de trabajadores y de las organizaciones políticas de la izquierda ${ }^{59}$. Si bien los objetivos inmediatos de la huelga no se alcanzaron, no es menos efectivo que ella dio origen a un proceso de acercamiento entre las diferentes organizaciones sociales y políticas de la clase obrera que, más tarde, cristalizaron en la formación del Frente Popular (6 de mayo de 1936) y de la Confederación de Trabajadores de Chile (25 al 17 de diciembre de 1936) ${ }^{60}$. Ambos referentes abrieron un nuevo ciclo en el desarrollo de la lucha política de la clase trabajadora, especialmente con la llegada al gobierno del Frente Popular en 1938, pero ello no puso fin a las tensiones y conflictos que atravesaban a sus diferentes organizaciones ni a los militantes que las integraban ${ }^{61}$.

58 "Contra el fascismo y la reacción, la unidad de la clase obrera", Consigna, Santiago de Chile, 15 de agosto, 1936, 2.

59 El uso de la tortura, en contra de los presos políticos por parte de los agentes de la policía de investigaciones, fue denunciando frecuentemente a través de la prensa de izquierda. Ver al respecto las acusaciones formuladas por el dirigente socialista Horacio Calderón: "Grillos, golpes, amenazas de muerte durante días de hambre e incomunicación”, Consigna, Santiago de Chile, 3 de junio, 1934, 4-6.

60 Mario Garcés y Pedro Milos, FOCH, CTCH, CUT, 49-69 y Alan Angell, Partidos políticos y movimiento obrero, 93-129. Un aliciente importante en este camino unitario fue el triunfo del Frente Popular en España en las elecciones del 16 de febrero de 1936. Cesar Godoy, "Carta política a propósito del triunfo de la izquierda en España”, Consigna, Santiago de Chile, 29 de febrero, 1936, 3. El evento de unidad sindical de diciembre de 1936 en: "Unidad obrera, promesa de libertad", Consigna, Santiago de Chile, 2 de enero, 1937, 4.

61 Este acercamiento fue tributario del "gran viraje" que experimentó la política del PCCh, a partir de su III Conferencia Nacional (1933) y que culminó con la adopción de la política frentepopulista definida por la III Internacional en su VII Congreso Mundial (1935). Sobre este punto ver, Sergio Grez, "Gran viraje del Partido Comunista de Chile. De 'clase contra clase' al Frente Popular (19281936)", Ponencia (Moscú: Conferencia Internacional "La Revolución rusa de 1917 y su lugar en el siglo XX", Instituto de Historia Universal de Academia de las Ciencias de Rusia, 28 de septiembre de 2017), 8-13 y Olga Ulianova, "Develando un mito: Emisarios de la Internacional Comunista en Chile”, Historia Vol. 1 No. 41 (2008): 125-144. Los recelos de los socialistas están consignados en la larga misiva que el máximo dirigente socialista, Oscar Schnacke, le hizo llegar a la dirección del PCCh 
La constitución del Frente Popular en 1936 y su rápido desarrollo político abrió una nueva etapa en las relaciones entre las diferentes organizaciones de la clase obrera. Si bien la cordialidad en muchas ocasiones parecía forzosa, no es menos efectivo que entre 1937 y 1939 las relaciones fueron bastante más amistosas que en el ciclo previo. En ello influyó, de manera decisiva, la identificación del fascismo, encarnado en Chile en el MNS, como enemigo y amenaza común. ${ }^{62}$ De la misma manera, la formalización de un programa compartido que enfatizaba la defensa del sistema democrático y la supresión de las leyes de carácter represivo, la agitación de una propuesta de desarrollo que defendía la planificación económica, la supresión de los monopolios y la ejecución de una política de reforma agraria y la reivindicación de la educación como una responsabilidad del Estado, posicionaba a los diferentes actores en torno a las mismas banderas y permitía, además, el encuentro de los mismos en los espacios locales (pueblos, haciendas, sindicatos, centros productivos, escuela, universidades, etc. $)^{63}$. Es más, para los socialistas el Frente Popular era mucho más que una alianza electoral que desplazaba a la oligarquía de la esfera del poder. Representaba la posibilidad histórica de llevar a cabo un profundo proceso de transformaciones económicas, sociales y políticas. No obstante, un proyecto de esta naturaleza exigía el reconocimiento y respeto de la autonomía de cada uno de los partidos integrantes de la coalición. ${ }^{64}$ No obstante, la conflictividad retornó en el momento mismo en que se asumió el control del aparato de gobierno y, en relación con ello,

el 22 de abril de 1935. Ver Oscar Schnacke, "Contestando al Partido Comunista", Consigna, Santiago de Chile, 1 de mayo, 1935, 4.

62 El Frente Popular estuvo integrado por los dos principales partidos de la clase obrera: Socialista y Comunista; por los partidos de centro ligados a la burocracia pública y al artesanado, como el Radical, el Demócrata y el radical Socialista; y por organizaciones sociales de base popular, como la Confederación de Trabajadores de Chile, el Frente Único Araucano y el Movimiento pro Emancipación de las Mujeres de Chile. Pedro Milos, Frente Popular en Chile. Su configuración: 1935-1938 (Santiago de Chile: LOM Ediciones, 2008) y Bárbara Silva, "La construcción nacional durante el Frente Popular chileno: Entre novedad y continuidad histórica, 1938-1941”, Revista Tiempo Histórico No. 14 (2017), 59-77.

63 "Programa del Frente Popular", Revista Hoy, Santiago de Chile, 5 de mayo, 1938, 18. Los antecedentes del Programa se encuentran en los discursos de quien llegó a ser Presidente de la República por el Frente Popular (1938-1941), Pedro Aguirre Cerda, "Los postulados de alimento, techo y abrigo", en Una carta y un discurso político del Presidente del Partido Radical don Pedro Aguirre Cerda (Santiago de Chile: Imprenta La República, 1934), 9-16.

64 "Aclarando situaciones", Consigna, Santiago de Chile, 14 de noviembre, 1936, 2. 
se desarrollaron disputas respecto de las áreas de influencia social y política y respecto de la composición de los cargos públicos.

Poco tiempo después el país, y por extensión los partidos políticos de izquierda, se vieron sorprendidos por la suscripción en Moscú (23 de agosto de 1939) del denominado Pacto Molotov-Ribbentrop, que ponía fin al enfrentamiento político e ideológico entre nazis y bolcheviques y abría una breve etapa de cooperación económica y política entre la Unión Soviética y Alemania. Los partidos comunistas adscritos a la III Internacional respaldaron la política exterior soviética abriendo con ello una nueva etapa de polémicas y conflictos con sus aliados socialistas. De esta polémica se hizo cargo rápidamente el periódico socialista consigna que en su editorial condenó "con toda energía" la invasión alemana a Polonia, la cual se habría visto avalada por el pacto suscrito por Hitler y Stalin. Para los socialistas esta pacto "vergonzoso" provocaba el descrédito de la Unión Soviética frente a la clase obrera y "la desmoralización de las propias filas comunistas" "65. Por su parte, el dirigente socialista Juan Balmes responsabilizaba del viraje soviético a Stalin y, al hacerlo, indicaba la absoluta falta de discusión interna en el Partido Comunista de ese país:

"Hoy en el país de Lenin que vivió toda su vida polemizando con sus propios compañeros de partido, hasta en las horas más aciagas de la revolución, no se discute, no se piensa, se aplaude tumultuosamente al genio cuyos destellos brillan más que el sol; todo se aprueba por unanimidad. Así ocurren las cosas en el país más democrático del mundo"66.

Por el contrario, para los comunistas chilenos el Pacto Molotov-Ribbentrop se inscribía en el despliegue de una política exterior soviética que tenía como fin ulterior la "preservación de la paz". Paz amenazada por las potencias imperialistas que pretendían empujar una agresión de la Alemania nazi contra la Unión Soviética, de manera tal que el

65 "La nueva guerra de Europa", Consigna, Santiago de Chile, 9 de septiembre, 1939, 3.

66 Juan Balmes, "Ellos mismos se acusan", Consigna, Santiago de Chile, 9 de septiembre, 1939, 2. Por su parte la editorial de la revista socialista Rumbo señalaba a propósito del respaldo de los comunistas chilenos a este pacto, "[...] no faltaran grupos comparsa que aplauden rabiosamente esta nueva estrategia a la manera de los bufones de los príncipes del Renacimiento". "Posición del PS frente a la guerra”, Rumbo, Santiago de Chile, octubre, 1939, 2. 
régimen de Stalin al suscribir el tratado de no agresión con Alemania había logrado proteger a los pueblos del este de Europa (bálticos, ucranianos, bielorrusos y rusos), de un eventual ataque fascista. Siendo así, el discurso socialista resultaba agraviante y ponía de manifiesto la creciente identificación de los socialistas con las potencias imperialistas occidentales ${ }^{67}$. En su intervención ante el XI Congreso del Partido Comunista de Chile, el secretario general de la organización, el abogado Carlos Contreras Labarca sostuvo:

"En ninguna época de la Historia, país alguno había prestado, como hoy la Unión Soviética servicios tan inmensos a la causa de la paz y de la libertad de los pueblos, a la causa de la emancipación del proletariado mundial. Estoy seguro de que este Congreso expresará unánimente su plena solidaridad con la política internacional independiente, brillante y genial del gran País de los Soviets [...] Propongo que este Congreso dirija a Stalin, al Partido, Comunista (bolchevique) de la URSS en nombre del pueblo $y$ de la clase obrera de-Chile, un caluroso cablegrama de felicitación [...]. (La sala, en pie, prorrumpe en una delirante ovación que impide oír las últimas palabras.)"68.

Si bien el proceso unitario derivó en la formación de alianzas sociales y políticas amplias, en las cuales quedaron cobijados referentes obreros y partidos pequeñoburgueses, no es menos efectivo que muchos analistas de izquierda miraban con preocupación el eventual derrotero de la misma. Por una parte se temía renunciar al proyecto revolucionario y dejarse absorber por alternativas reformista y, por otro lado, se consideraba que la estrategia electoral no era suficiente para arrebatarle el poder a la oligarquía ${ }^{69}$. Estas premisas y su operacionalización política

67 Carlos Contreras Labarca denomina al Partido Socialista: "agencia mercenaria del imperialismo yanqui", en "La brutal agresión fascista contra la Unión Soviética", Principios No. 1 julio (1941): 8, mientras que Elías Lafertte acusaba a los dirigentes socialistas (Grove y Schnacke) de ser "trotskistas" y "traidores a la clase obrera". Elías Lafertte, "Informe presentado al pleno del comité central del Partido Comunista de Chile", en El Frente Popular vive y vencerá (Santiago de Chile: Partido Comunista de Chile, 1941), 16. La identificación de algunos dirigentes socialistas chilenos con el sistema político norteamericano en: María Soledad Gómez, El partido Socialista chileno y Estados Unidos: 1933-1946 (Santiago de Chile: FLACSO, 1984), 30-67.

68 Carlos Contreras, Informe ante el XI Congreso Nacional del Partido Comunista de Chile (Santiago de Chile: Editorial Ercilla, 1939), 43.

69 César Godoy, "Los partidos obreros y el Frente Popular", Consigna, Santiago de Chile, 9 de mayo, $1936,3$. 
fueron tensionando las relaciones entre los partidos de izquierda llevando gradualmente a la ruptura del Frente Popular. En enero de 1941, pocos días antes de la disolución de esta coalición los socialistas diagnosticaban que el referente se acercaba a su "despeñadero" y enfatizaban que la responsabilidad de dicha crisis radicaba tanto en la política de "cerco" de la oposición oligárquica, como en la política ambivalente de la "agencia criolla de la III Internacional" respecto del fascismo ${ }^{70}$. Expresión material de esta tensión fueron una serie de enfrentamientos entre trabajadores socialistas y comunistas que alcanzó su punto más alto en la cuenca carbonífera de Lota, donde un grupo de militantes socialistas fue brutalmente agredido por sus trabajadores comunistas ${ }^{71}$.

\section{Conclusiones}

La historiografía social ha colocado el acento en la construcción de las identidades sociales populares, enfatizando los rasgos distintivos de la cultura obrera. En ella aparecen sistemáticamente revelados su capacidad para construir asociaciones cooperativas y de resistencia, los vínculos de solidaridad y camaradería que se entretejen en los campamentos mineros y en los centros fabriles, los amplios y complejos repertorios de acción colectiva, y su capacidad para adaptarse a una institucionalidad siempre cambiante. Todos aspectos ampliamente validados por el quehacer investigativo. No obstante, las tensiones y conflictos que enfrentaron a los trabajadores con las élites dirigentes y sus representaciones políticas y aquellos que incluso enfrentaron a los militantes de la clase obrera entre sí, no aparecen suficientemente analizados.

En este artículo hemos podido observar que, en una fase particularmente crítica de la vida política del país, la conflictividad se extendió ampliamente y derivó en la configuración de escenarios violentos, de diferente naturaleza. En algunos casos, los más sangrientos, la violencia se manifestó a través del uso masivo y sistemático de la fuerza pública en contra de las movilizaciones obreras y populares mientras que, en otros, fueron las bandas armadas de la derecha las que operaron

\footnotetext{
70 "Unidad popular sin traidores", Consigna, Santiago de Chile, 18 de enero, 1941, 1.

71 "Comunistas aliados con la derecha", Consigna, Santiago de Chile, 18 de enero, 1941, 4.
} 
bajo el amparo de la autoridad, castigando duramente a los trabajadores. No obstante, los trabajadores no permanecieron inermes frente a las violencias represivas. Circunstancialmente devolvieron los golpes, aunque la efectividad de los mismos fue reducida dada la precariedad de sus armamentos y el arraigo temprano que adquirieron en Chile las prácticas políticas intrainstitucionales.

Por último, hemos podido acreditar la existencia de una profusa conflictividad entre las organizaciones obreras. Una parte relevante de la misma se expresó como diatribas y cuestionamientos a la valides de las tesis de los adversarios o a su idoneidad política y moral. Pero, en no pocas ocasiones dicha conflictividad derivó hacia escenarios de violencia, circunstancia en las cuales muchos resultaron gravemente heridos y otros perdieron la vida. El conjunto de estos fenómenos acredita que la violencia se constituyó en un campo más de la acción política y que la misma se encuentra profundamente arraigada en las prácticas políticas de los actores colectivos de Chile.

\section{Bibliografía}

\section{Fuentes Primarias}

\section{Periódicos}

Consigna, Santiago de Chile, 1934-1940.

El Radical Socialista, Santiago de Chile, 1933.

El Reflector, Illapel, 1938.

El Socialista, Concepción, 1934.

La Chispa, Santiago de Chile, 1931.

La Nación, Santiago de Chile, 1933.

Núcleo, Valparaíso, 1934.

Principios, Santiago de Chile, 1941.

Revista Hoy, Santiago de Chile, 1938.

Rumbo, Santiago de Chile, 1939.

Trabajo, Santiago de Chile, 1936. 


\section{Fuentes Secundarias}

Acevedo, Nicolás. "Autonomía y movimientos sociales. La Liga de Campesinos Pobres y la izquierda chilena (1935-1942)". Revista Izquierdas No. 23 (2015): 44-65.

Acevedo, Nicolás. Un fantasma recorre el campo. Comunismo y politización campesina en Chile (1935-1948). Valparaíso: Editorial América en Movimiento, 2017.

Aguirre Cerda, Pedro. "Los postulados de alimento, techo y abrigo". En Una carta y un discurso político del Presidente del Partido Radical don Pedro Aguirre Cerda. Santiago de Chile: Imprenta La República, 1934: 9-16.

Álvarez, Rolando. "La matanza de La Coruña. Chile, 1925". Contribuciones Científicas y Tecnológicas No. 116 (1997): 77-108. Angell, Alan. Partidos políticos y movimiento obrero en Chile. De los orígenes hasta el triunfo de la Unidad Popular. México: Ediciones ERA, 1974.

Araya, Mario. "Los wobblies criollos: Fundación e ideología en la región chilena de la Industrial Workers of the World - IWW (19191927)". ('Tesis de Licenciatura en Historia, Universidad ARCIS, 2008).

Barnard, Andrew. "El Partido Comunista de Chile y las políticas del tercer periodo, 1931-1934”. En 1912-2012 El siglo de los comunistas chilenos, editado por Olga Ulianova, Manuel Loyola y Rolando Álvarez. Santiago de Chile: Instituto de Estudios Avanzados, 2012, 115-169.

Barnard, Andrew. El Partido Comunista de Chile, 1922-1947. Santiago de Chile: Ariadna Ediciones, 2017.

Barría, Jorge. El movimiento obrero en Chile, Síntesis histórico-social. Santiago de Chile: Ediciones de la Universidad Técnica del Estado, 1971.

Benavides, Leopoldo. La formación de la izquierda chilena. Relaciones entre el Partido Comunista y el Partido Socialista. Los antecedentes históricos. Santiago de Chile: Documento de Trabajo FLACSO No. 389, 1988.

Bonnassiolle, Marcelo. "A ganar las calles y cambiar la nación. Conflictividad social, violencia y represión estatal en la lucha antifascista y 
antimarxista en Chile, 1932-1938" (Tesis de Maestría en Historia,

Universidad de Santiago de Chile, 2016).

Contreras, Carlos. Informe ante el XI Congreso Nacional del Partido

Comunista de Chile. Santiago de Chile: Editorial Ercilla, 1939.

Correa, Sofía. Con las riendas del poder. La derecha chilena en el siglo XX. Santiago de Chile: Debolsillo, 2016.

Cruz, Luis. La República Socialista del 4 de junio. Santiago de Chile: Ediciones de la Biblioteca Clodomiro Almeyda, 2012.

De Shazo, Peter. Trabajadores urbanos y sindicatos en Chile: 19021927. Santiago de Chile, DIBAM, 2007.

Drake, Paul. Socialismo y populismo Chile, 1936-1973. Valparaíso: Universidad Católica de Valparaíso, 1992.

Durán, Francisca. "Definiendo rumbos: la FOCH entre la acción sindical y la acción política”. Revista Izquierdas Vol. 2 No. 3 (2009): 2-7.

Estado de Chile. "Decreto con fuerza de Ley $N^{\circ} 143$ ". Santiago de Chile 6 de mayo (1931).

Estado de Chile. "Decreto Ley N ${ }^{\circ}$ 50". Santiago de Chile 24 de junio (1932).

Estado de Chile. “Ley N³.026”. Santiago de Chile 12 de febrero (1937). Faundez, Julio. Democratización, desarrollo y legalidad. Chile, 18311973. Santiago de Chile: Universidad Diego Portales, 2011.

Flores, Jaime, "Un episodio en la historia social de Chile 1934, Ranquil:

Una revuelta campesina”. (Tesis de Maestría en Historia, Universidad de Santiago de Chile, 1993).

FOCH. Hagamos la unidad de todos los obreros del país para luchar contra el hambre y la reacción. Santiago de Chile: FOCH, 1934.

Garcés, Mario y Milos, Pedro. FOCH, CTCH, CUT. Las centrales unitarias en la historia del sindicalismo chileno. Santiago de Chile: Educación y Comunicaciones, 1988.

Gómez, María Soledad. El partido Socialista chileno y Estados Unidos: 1933-1946. Santiago de Chile: FLACSO, 1984.

Grez, Sergio. "Un episodio de las políticas del tercer período de la Internacional Comunista: Elecciones presidenciales en Chile, 1931”. Historia Vol. 48 No. 2 (2015): 465-503. 
Grez, Sergio. El Partido Democrático de Chile. Auge y ocaso de una organización política popular (1887-1927). Santiago de Chile: LOM Ediciones, 2016.

Grez, Sergio. Gran viraje del Partido Comunista de Chile. De 'clase contra clase' al Frente Popular (1928-1936)”. Ponencia. Moscú: Conferencia Internacional "La Revolución rusa de 1917 y su lugar en el siglo XX", Instituto de Historia Universal de Academia de las Ciencias de Rusia, 28 de septiembre de 2017.

Grez, Sergio. Historia del comunismo en Chile. La era de Recabarren (1912-1924). Santiago de Chile: LOM Ediciones, 2011.

Grez, Sergio. Los anarquistas y el movimiento obrero. La alborada de la idea en Chile, 1893-1915. Santiago de Chile: LOM Ediciones, 2007.

Grove, Jorge. Descorriendo el velo. Episodio de los doce días de la República Socialista. Santiago de Chile: Folleto, Valparaíso, 1933.

Jobet, Julio César. El Partido Socialista de Chile, vol. 1. Santiago de Chile: Ediciones Prensa Latinoamericana, 1971.

Lafertte, Elías. "Informe presentado al pleno del comité central del Partido Comunista de Chile". En El Frente Popular vive y vencerá. Santiago de Chile: Partido Comunista de Chile, 1941, 16.

Loyola, Manuel. "La Federación Juvenil Comunista (1931-1934)". En Un trébol de cuatro hojas. Las Juventudes Comunistas de Chile en el siglo XX, editado por Rolando Álvarez y Manuel Loyola. Santiago: Ariadna Ediciones y Editorial América en Movimiento, 2014, 38-54.

Magasich, Jorge. Los que dijeron No. Historia del movimiento de los marinos antigolpistas de 1973, vol. 1. Santiago de Chile, LOM Ediciones, 2008.

Marfán, Manuel. "Políticas reactivadoras y recesión externa: Chile 19291938”. Estudios CIEPLAN No. 12 (1984): 89-119.

Milos, Pedro. Frente Popular en Chile. Su configuración: 1935-1938. Santiago de Chile: LOM Ediciones, 2008.

Partido Socialista. Estatutos de las Milicias Socialistas. Santiago de Chile: Imprenta Darricarrere, 1938.

Pinto, Julio. "Socialismo y salitre: Recabarren, Tarapacá y la formación del Partido Obrero Socialista". Historia Vol. 32 (1999): 315-366. 
Pinto, Julio. Luis Emilio Recabarren. Una biografía histórica. Santiago de Chile: LOM Ediciones, 2013.

Pizarro, Crisóstomo. La huelga obrera en Chile. Santiago de Chile: Ediciones SUR: 1986.

Portales, Felipe. Los mitos de la democracia chilena. Vol. II desde 1925 a 1938. Santiago de Chile: Editorial Catalonia, 2010.

Rojas, Jorge. La dictadura de Ibáñez y los sindicatos (1927-1931). Santiago de Chile: DIBAM, 1993.

Santibáñez, Camilo. "La IWW y el movimiento obrero en Chile: El caso de los obreros portuarios nortinos (1919-1923). Diálogo Andino No. 55 (2018): 19-28.

Sater, William F. "The abortive Kronstadt: The chilean naval mutiny of 1931". The Hispanic American Historical Review Vol. 60 No. 2 (mayo 1980): 239-268.

Silva, Bárbara. "La construcción nacional durante el Frente Popular chileno: Entre novedad y continuidad histórica, 1938-1941”. Revista Tiempo Histórico No 14 (2017): 59-77.

Tellez, Eduardo et al. "El levantamiento del alto Biobío y el soviet y la república araucana de 1934". Anales de la Universidad de Chile No. 13 sexta serie (2001).

Ulianova, Olga. "Develando un mito: Emisarios de la Internacional Comunista en Chile". Historia Vol. 41 No. 1 (2008): 125-144.

Ulianova, Olga. "Levantamiento campesino de Lonquimay y la Internacional Comunista”. Estudios Públicos No. 89 (2003): 173-223.

Urtubia, Ximena. Hegemonía y cultura política en el Partido Comunista de Chile. La transformación del militante tradicional (1924-1933). Santiago de Chile: Ariadna Ediciones, 2017.

Valdivia, Verónica. "El ocaso del salitre: Navidad en Copiapó y Vallenar. Chile, 1931". Boletín del Instituto de Historia Argentina y Americana "Dr, Emilio Ravignani" Tercera Serie No. $19\left(1^{\circ}\right.$ semestre 1999): 81-114.

Valdivia, Verónica. “Las Milicias Socialistas, 1934-1941”. Mapocho. Revista de Humanidades y Ciencias Sociales No. 33 (Primer Semestre 1993): 157-180.

Valdivia, Verónica. "Los tengo plenamente identificados. Seguridad interna y control social en Chile, 1918-1925". Historia Vol. 50 No. 1 (2017): 241-271. 
Valdivia, Verónica. La Milicia Republicana, Los civiles en armas, 1932 1936. Valparaíso: Editorial América en Movimiento, 2016.

Vega, Mariano. "¿Hidalguismo versus lafertismo? Crisis y disputa por la representación del comunismo en Chile, 1929-1933”. En 19122012 El siglo de los comunistas chilenos, editado por Olga Ulianova, Manuel Loyola y Rolando Álvarez. Santiago de Chile: Instituto de Estudios Avanzados, 2012, 97-114.

Venegas, Daniel. "La concepción nacista de la sociedad: Posición doctrinaria en torno al sujeto del cambio y las organizaciones de trabajadores". Revista de Historia Vol. 26 No 1 (2019): 59-82.

Para citar este artículo: Goicovic Donoso, Igor. "Inestabilidad, Conflictividad y Violencia Política en Chile, 1925-1941", Historia Caribe Vol. XVI No. 39 (Julio-Diciembre 2021):59-92. DOI: https:// doi.org/10.15648/hc.39.2021.2960 